\title{
Herpes Simplex Virus 1, Cytomegalovirus and Epstein Barr Virus Detection in Patients with Chronic and Aggressive Periodontitis
}

\author{
Harold H. Hernández*, Andreína S. Fernandes, Laura A. Escalona, María Correnti \\ Institute of Dental Research "Raúl Vincentelli", Faculty of Dentistry, Central University of Venezuela, Caracas, \\ Venezuela \\ Email: "haroldhernandez2001@hotmail.com
}

Received 6 March 2016; accepted 21 March 2016; published 25 March 2016

Copyright (C) 2016 by authors and OALib.

This work is licensed under the Creative Commons Attribution International License (CC BY). http://creativecommons.org/licenses/by/4.0/

(c) (i) Open Access

\section{Abstract}

Recent investigations suggest that the viruses of the family Herpesviridae are associated with periodontal disease, demonstrating a possible association with the presence of Human Cytomegalovirus (HCMV), Herpes Simplex Virus 1 (HSV-1) and Epstein Barr Virus (EBV) in periodontal tissues. Aim: To analyze the association between the presence of HSV-1, HCMV and EBV in patients with chronic or aggressive periodontitis. Methods: Crevicular fluid samples were collected from 11 patients with aggressive periodontitis (AgP), 11 with chronic periodontitis (CP) and 11 healthy control subjects (CG). The following clinical parameters were measured: plaque index (PI), bleeding on probing (BOP), probing depths (PD) and clinical attachment loss (CAL). Viral detection was performed by PCR for HSV-1, HCMV and EBV. Results: HCMV was detected in 27.3\% of AgP patients but not detected in CP and healthy subjects; HSV-1 in 27.3\% of AgP and CP group and in 9.1\% of CG. EBV-1 was detected in $18.2 \%$ of CP patients and 9.1\% of the CG. HCMV and HSV-1 coinfection was detected in $18.8 \%$ of AgP patients and $9.09 \%$ of viral coinfection between HSV-1 and VEB, within the CP group. The AgP group exhibited the higher values for all clinical parameters evaluated, respect to the CP and control group. Conclusion: The presence of HCMV may be related to periodontal disease, specifically in cases of AgP, and it may play a synergistic role with other infectious agents from the oral cavity associated with the development of periodontitis.

\section{Keywords}

Periodontitis, Gingival Crevicular Fluid, Cytomegalovirus, Herpes Simplex Virus, Epstein Barr Virus

\section{Subject Areas: Dentistry, Virology}

\footnotetext{
${ }^{*}$ Corresponding author.
}

How to cite this paper: Hernández, H.H., Fernandes, A.S., Escalona, L.A. and Correnti, M. (2016) Herpes Simplex Virus 1 , Cytomegalovirus and Epstein Barr Virus Detection in Patients with Chronic and Aggressive Periodontitis. Open Access Library Journal, 3: e2557. http://dx.doi.org/10.4236/oalib.1102557 


\section{Introduction}

The pathogenesis of periodontal disease is a complex process, associated to a multifactorial interactions between microbial and host factors [1]. Recently, Herpes Simplex Virus 1 (HSV-1), human Cytomegalovirus (HCMV) and Epstein Barr Virus (EBV) have been implicated in the pathogenesis of periodontal disease. In fact, various studies indicate the role of these viruses in the different types of periodontal disease, even though they are frequently not diagnosed in clinical practice [2]. Today, the presence of HSV-1, HCMV and EBV is considered as an important factor in the progression of periodontal disease [3].

In the mid-seventies the possible relationship between viral infection and oral diseases became a matter of study, specifically HSV in the crevicular fluid and the junctional epithelium of the gingival sulcus, including epithelial cells and fibroblasts [4] [5]. In the eighties, other studies evaluated the presence of IgG and IgA antibodies against HSV, in its latent phase and onset of herpetic lesions, in gingival fluid by immunofluorescence. These investigations were seeking to find other possible locations of the oral cavity like periodontal tissue and gingival fluid which would function as a reservoir of virus, associated with its different phases of virulence [6]-[12].

At the end of the nineties, investigations began to establish a more direct relationship between Herpesviruses and periodontal disease, based on more sensitive and specific tests, such as the Polymerase Chain Reaction (PCR), which is based on the detection of specific sequences of the viral genome. Several studies worked with dental biofilm samples from patients with chronic periodontitis (CP) and aggressive periodontitis (AgP), in which they determined that the virus found with higher prevalence was HSV, HCMV and EBV [13]-[17].

Parra and Slots [18], reported 78\% of HSV positivity in patients with periodontitis and 31\% in patients with gingivitis. Contreras et al. [12] found a prevalence of 59\% for HCMV, 27\% for EBV-1 and 23\% for HSV, in crevicular fluid samples in Nigerian children with ulcerative gingivitis and malnutrition. Botero et al. [19] reported a frequency of detection for HCMV about $60 \%$ in patients with periodontitis, compared with $4.1 \%$ in periodontally healthy subjects. Eres et al. [20] showed that lesions of gingivitis in pregnant women were positive in $38.6 \%$ and $14.3 \%$ for EBV and HCMV, respectively. In the non-pregnant group, EBV and HCMV were detected in $15 \%$ and $20 \%$ of the lesions.

The results of these investigations indicate that the presence of HSV-1, HCMV and EBV in gingival tissues was frequently detected, as well as pathological pockets and saliva. However, although the HSV, HCMV and EBV are not the direct etiological factor of periodontal disease, their presence becomes an adverse factor that could worsen the course and prognosis of the disease.

Periodontitis is a periodontal disease with a prevalence of more than $50 \%$ in patients over 40 years, which has been associated with the presence of viral agents easily transmissible. In Venezuela there are not reports about the presence of the Herpesviruses in samples of gingival fluid of patients with periodontitis. This first study may allow better understanding of the behavior of some patients, despite complying with traditional periodontal treatment, do not present a favorable evolution, which could be related to the cytopathic effects caused by the virus in the periodontal tissue. So there may be developing protocols for viral detection in the growing number of patients attending periodontal consultation to improve oral health. As a result, a new interest has arisen to analyze the association between the presence of HSV-1, HCMV and EBV with CP and AgP, and evaluate its relationship with periodontal clinical parameters.

\section{Materials and Methods}

\subsection{Specimen Collection}

33 crevicular fluid samples were collected from 11 patients with diagnosis of AgP, 11 patients with diagnosis of $\mathrm{CP}$ and 11 periodontal and systemically healthy control group (CG), which were attended at the Postgrade of Periodontics, Faculty of Dentistry, of the Universidad Central de Venezuela, from November 2012 to February 2013. The criteria for the diagnosis of CP and gingivitis were based on the Classification of the Periodontal Diseases issued by the American Academy of Periodontology in 1999 [21]. Each patient signed an informed consent, supported by the Bioethics Committee of the faculty. Each patient underwent a complete periodontal and radiographic examination, excluding third molars, using a periodontal probe (University of North Carolina). The following periodontal clinical parameters were recorded: Probing depth (PD), clinical attachment loss (CAL), bleeding on probing (BOP) and index of dental biofilm (PI) [22]. 
The sample in the periodontitis patients group was collected from the deepest periodontal pockets and in the CG from the healthy gingival sulcus. The sites under study were isolated with cotton rolls and the supragingival plaque was removed with sterile gauze; a sterile paper tips were introduced to the bottom of the sulcus. The tips were held in place for 20 seconds and were transferred to a $1.5 \mathrm{ml}$ Eppendorf tube and stored at $-80^{\circ} \mathrm{C}$ until viral analysis.

\subsection{Viral Detection}

The isolation of the nucleic acids was performed using the Pure Link Genomic DNA Kit (InvitrogenTM, CA, USA), following the specifications of the manufacturer and the quality evaluation of the DNA was conducted with the BIOMED-2 protocol [23].

Viral detection was performed by PCR, using Herpes Simplex virus type 1 DNA polymerase, Primer Set Kit (Maxim Biotech. Inc, CA, USA) and Virus Cytomegalovirus (CMV) Major Immediately early, Primer Set kit (Maxim Biotech. Inc, CA, USA) for HSV-1 and HCMV, respectively, following the recommendations of the manufacturer.

For the detection of EBV a nested PCR was performed. Primer sequences for the first round were: (W1) 5'-CTAGGGGAGAACGTGAA-3' and (W2)'-CTGAAGGTGAACCGCTTACCA-3'. Primer sequences for the second round were: (W3) 5'-GGTATCGGGCCAGAGGTAAGT-3' and (W4)

5'-GCTGGACGAGGACCCTTCTAC-3'. The reactions were carried out in a final volume of $22.5 \mu$ l, containing $6 \mu \mathrm{l}$ of $10 \mathrm{X}$ buffer, $1 \mu \mathrm{l}$ of $\mathrm{MgCl} 2(50 \mathrm{mM}), 2 \mu \mathrm{l}$ of dNTP's $(10 \mathrm{mM}), 0.5 \mu \mathrm{l}$ of Taq polymerase, $0.5 \mu \mathrm{l}$ of each primer ( $20 \mathrm{pmol}), 12 \mu \mathrm{l}$ of nuclease-free water and $8 \mu \mathrm{l}$ of genomic DNA. After the first round, $2 \mu \mathrm{l}$ of the final product were taken and transferred to the mixture for the second round of amplification. The first PCR cycling program included 4 min at $94^{\circ} \mathrm{C}$; then 30 cycles with each cycle consisting of a step at $94^{\circ} \mathrm{C}$ for $45 \mathrm{~s}$, followed by a step at $66^{\circ} \mathrm{C}$ for $30 \mathrm{~s}$ and a last step at $72^{\circ} \mathrm{C}$ for $45 \mathrm{~s}$. Finally, $5 \mathrm{~min}$ at $72^{\circ} \mathrm{C}$. The second PCR cycling program included $4 \mathrm{~min}$ at $94^{\circ} \mathrm{C}$; then 40 cycles with each cycle consisting of a step at $94^{\circ} \mathrm{C}$ for $45 \mathrm{~s}$, followed by a step at $66^{\circ} \mathrm{C}$ for $30 \mathrm{~s}$ and a last step at $72^{\circ} \mathrm{C}$ for $45 \mathrm{~s}$. Finally, $5 \mathrm{~min}$ at $72^{\circ} \mathrm{C}$.

Viral PCR products were visualized by $2 \%$ agarose gel electrophoresis and with SYBR Safe (InvitrogenTM, CA, USA) stained. The photographic record was made with a ChemiDoc XRS (BioRad). The amplicons sizes were: HSV-1: 105 bp, HCMV: 435 bp, EBV: 192 bp.

\subsection{Statistical Analysis}

t-Student and Chi square test was performed to evaluate the independence of the variables, with the IBM SPSS software, version 2.0. Values less than or equal to 0.05 were considered statistically significant.

\section{Results}

The total study sample was 33 patients, divided into 11 cases of AgP (9 women and 2 men; mean age $24.27 \pm$ 7.67 years, range 14 - 39), 11 cases of CP ( 6 women and 5 men, mean age $43.82 \pm 11.11$ years, range 29 - 58) and 11 cases of subjects without periodontal disease (8 women and 3 men, mean age $40.09 \pm 10.98$ years, range: 28 - 61). Following DNA extraction, the nucleic acids quality was analyzed by the BIOMED-2 protocol, showing that both samples of periodontitis patients, such as those of healthy individuals amplified all target genes, indicating that the genetic material obtained was in optimum condition for the subsequent detection of the corresponding viral genomes, therefore avoiding false negatives.

Figure 1 shows a set of study samples for the detection of viral agents, in the group of patients with periodontitis and healthy subjects group. In the case of $\operatorname{HCMV~(A)~a~single~band~of~} 435$ bp was amplified. For EBV (B), the amplified band was 192 bp and for HSV-1 (C) the amplified band was 105 bp.

Table 1 shows the viral distribution, according to the study group. In the group with AgP, the rate of viral infection was 27.3\% (3/11) for HCMV and HSV-1 for each one. EBV was not detected. The presence of HCMV in AgP group was statistically significant $(p=0.037)$. In the group with $C P$, the viral detection was higher for HSV-1 with 27.3\% (3/11), followed by EBV with 18.2\% (2/11), and HCMV was not detected. Finally, in the CG, the percentage of viral infection was $0 \%$ for HCMV, 9.1\% (1/11) for HSV-1 and 9.1\% (1/11) for EBV. Assessing the presence of mixed infections in the study groups, we found $18.2 \%(2 / 11)$ of viral co-infection between HCMV and HSV-1 within the AgP group, and 9.1\% (1/11) of viral co-infection between HSV-1 and VEB, within the CP group. 


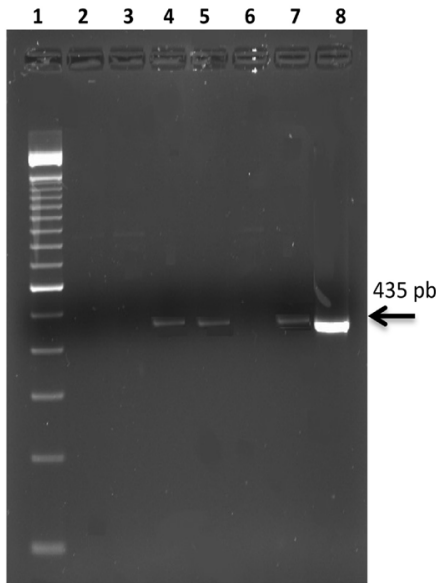

(a)

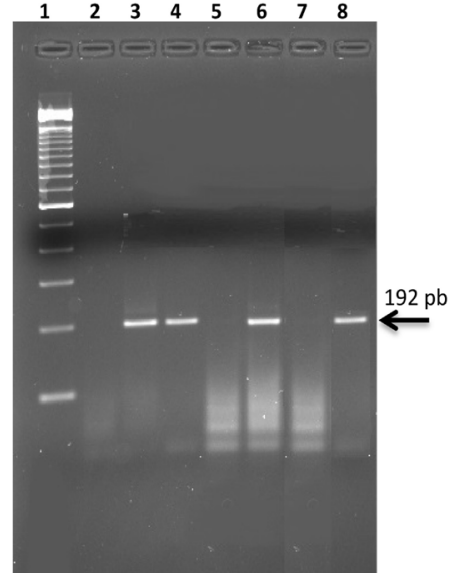

(b)

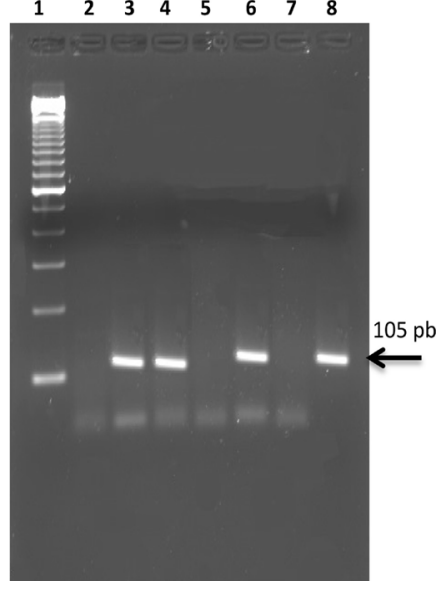

(c)

Figure 1. Amplified products of HCMV (a); EBV (b) and HSV-1 (c) by PCR. Lane 1: molecular weight marker, lane 2: negative control, lanes 3 - 7: study samples, lane 8: positive control.

Table 1. Herpesviruses detection frequency in patients with aggressive periodontitis, chronic periodontitis and control group.

\begin{tabular}{|c|c|c|c|c|c|c|c|c|}
\hline \multirow{2}{*}{ Viruses } & \multicolumn{2}{|c|}{ AgP } & \multicolumn{2}{|c|}{$\mathrm{CP}$} & \multicolumn{2}{|c|}{ CG } & \multirow{2}{*}{$p$ value $^{\mathrm{a}}$} & \multirow{2}{*}{$\mathrm{Chi}^{2}$} \\
\hline & $+(\mathrm{N}) \%$ & $-(\mathrm{N}) \%$ & $+(\mathrm{N}) \%$ & $-(\mathrm{N}) \%$ & $+(\mathrm{N}) \%$ & $-(\mathrm{N}) \%$ & & \\
\hline HCMV & (3) 27.3 & (8) 72.7 & 0 & (11) 100 & 0 & 100 & $0.037^{*}$ & 6.600 \\
\hline HSV-1 & (3) 27.3 & (8) 72.7 & (3) 27.3 & (8) 72.7 & (1) 9.1 & 90.9 & 0.484 & 1.451 \\
\hline EBV & 0 & (11) 100 & (2) 18,2 & (9) 81.8 & (1) 9.1 & 90.9 & 0.333 & 2.200 \\
\hline
\end{tabular}

${ }^{\mathrm{a}} p<0.05$.

The general values of the clinical parameters from all patients of the study are shown in Table 2. The group with AgP exhibited the higher values for most of the clinical parameters evaluated, respect to the CP and CG ( $p$ $<0.001)$.

The clinical parameters comparison related to the presence of HCMV, HSV-1 and EBV are shown in Tables 3-5. With regard to the detection of HCMV (Table 3), there was no statistically significant difference between the positive and negative patients for viral detection, diagnosed with AgP, however the BOP value was in the borderline. With respect to HSV-1 detection (Table 4), the clinical parameters for the positive patients were not significantly different in comparison with the negative patients, except for BOP values in the AgP group, which were in the borderline. Finally, there were no significant differences between EBV positive and negative patients, respect to clinical parameters (Table 5).

\section{Discussion}

Recent research has suggested that viruses of the Herpesviridae family are related to periodontal disease, demonstrating a possible association with the presence of HCMV, HSV-1 and EBV in periodontal tissues with the pathogenesis of periodontitis [24] [25]. Generally, has been reported a frequency of infection between $20 \%-70 \%$ for HCMV, 14\% - 70\% for EBV and 7\% - 90\% for HSV-1, worldwide [26].

In this study, a statistically significant relationship between AgP and the presence of HCMV was determined, with a percentage of viral infection of $27.3 \%$, whereas in the CP group and CG was not detected. Other studies show a significant association with the presence of HCMV in samples from patients with AgP, some of them with significantly higher detection frequency, between $45 \%$ and $72.7 \%$ [19] [27]-[30]. However, other works shows lower detection rates, between $6 \%$ and 12\% [1] [31] [32]. Sharma et al. [30] reported a frequency of HCMV and EBV positive for $45 \%$ in the aggressive periodontitis and 20 and $25 \%$, respectively, in the group of chronic periodontitis. For the control group, reported a frequency of $10 \%$ and $0 \%$ for HCMV and EBV, respectively. 
Table 2. Clinical parameters of the study groups, including aggressive and chronic periodontitis, and the control group.

\begin{tabular}{cccc}
\hline & AgP & CP & CG \\
\hline PD (mm) & $9.45 \pm 2.38^{\mathrm{ab}}$ & $4.72 \pm 1.27^{\mathrm{c}}$ & $1.72 \pm 0.64$ \\
CAL (mm) & $8.45 \pm 2.42^{\mathrm{ab}}$ & $4.63 \pm 1.36^{\mathrm{c}}$ & $1.36 \pm 0.50$ \\
BOP & $0.90 \pm 0.30^{\mathrm{b}}$ & $1.00 \pm 0^{\mathrm{c}}$ & $0.09 \pm 0.30$ \\
PI & $2.36 \pm 0.50^{\mathrm{b}}$ & $2.72 \pm 0.78^{\mathrm{c}}$ & $0.36 \pm 0.50$ \\
\hline
\end{tabular}

${ }^{\mathrm{a}} p<0.05$ compared to the CP group (t-Student); ${ }^{\mathrm{b}} p<0.05$ compared to the CG group (t-Student); ${ }^{\mathrm{c}} p<0.05$ compared to the CG group ( $t$-Student).

Table 3. Comparison of clinical parameters with the presence of HCMV in patients with aggressive periodontitis.

\begin{tabular}{|c|c|c|c|c|}
\hline \multirow{2}{*}{ Parameter } & \multirow{2}{*}{ HCMV } & \multicolumn{3}{|c|}{ AgP } \\
\hline & & $\mathrm{N}$ & Average & $p$ value $^{\mathrm{a}}$ \\
\hline \multirow{2}{*}{ PD } & + & 3 & $9.3 \pm 1.15$ & \multirow{2}{*}{0.752} \\
\hline & - & 8 & $9.1 \pm 2.84$ & \\
\hline \multirow{2}{*}{ CAL } & + & 3 & $8.66 \pm 1.52$ & \multirow{2}{*}{0.639} \\
\hline & - & 8 & $7.89 \pm 2.97$ & \\
\hline \multirow{2}{*}{ BOP } & + & 3 & $0.66 \pm 0.57$ & \multirow{2}{*}{0.087} \\
\hline & - & 8 & $1.00 \pm 0$ & \\
\hline \multirow{2}{*}{ PI } & + & 3 & $2.40 \pm 0.55$ & \multirow{2}{*}{0.898} \\
\hline & - & 8 & $2.33 \pm 0.50$ & \\
\hline
\end{tabular}

${ }^{\mathrm{a}} p \leq 0.05$ (Chi ${ }^{2}$ test).

Table 4. Comparison of clinical parameters with the presence of HSV-1 in patients with aggressive periodontitis, chronic periodontitis and control group.

\begin{tabular}{|c|c|c|c|c|c|c|c|c|c|c|}
\hline \multirow{2}{*}{ Parameters } & \multirow{2}{*}{ HSV1 } & \multicolumn{3}{|c|}{ AgP } & \multicolumn{3}{|c|}{$\mathrm{CP}$} & \multicolumn{3}{|c|}{ CG } \\
\hline & & $-\mathrm{N}$ & Average & $p$ value $^{\mathrm{a}}$ & $-\mathrm{N}$ & Average & $p$ value $^{\mathrm{a}}$ & $-\mathrm{N}$ & Average & $p$ value $^{\mathrm{a}}$ \\
\hline \multirow{2}{*}{$\mathrm{PD}$} & + & 3 & $9.00 \pm 1.00$ & \multirow{2}{*}{0.583} & 3 & $5.33 \pm 1.52$ & \multirow{2}{*}{0.781} & 1 & $1.00 \pm 0$ & \multirow{2}{*}{0.382} \\
\hline & - & 8 & $9.62 \pm 2.77$ & & 8 & $4.50 \pm 1.19$ & & 10 & $1.80 \pm 0.63$ & \\
\hline \multirow{2}{*}{ CAL } & + & 3 & $7.67 \pm 1.15$ & \multirow{2}{*}{0.266} & 3 & $3.33 \pm 1.15$ & \multirow{2}{*}{0.292} & 1 & $1.00 \pm 0$ & \multirow{2}{*}{0.428} \\
\hline & - & 8 & $8.75 \pm 2.76$ & & 8 & $5.12 \pm 1.12$ & & 10 & $1.40 \pm 0.51$ & \\
\hline \multirow{2}{*}{ BOP } & + & 3 & $0.66 \pm 0.57$ & \multirow{2}{*}{0.087} & 3 & $1.00 \pm 0$ & \multirow[b]{2}{*}{ S } & 1 & 0 & \multirow{2}{*}{0.740} \\
\hline & - & 8 & $1.00 \pm 0$ & & 8 & $1.00 \pm 0$ & & 10 & $0.10 \pm 0.31$ & \\
\hline \multirow{2}{*}{ PI } & + & 3 & $2.33 \pm 0.57$ & \multirow{2}{*}{0.898} & 3 & $2.66 \pm 0.57$ & \multirow{2}{*}{0.557} & 1 & 0 & \multirow{2}{*}{0.428} \\
\hline & - & 8 & $2.37 \pm 0.51$ & & 8 & $2.12 \pm 0.83$ & & 10 & $0.40 \pm 0.51$ & \\
\hline
\end{tabular}

${ }^{\mathrm{a}} p \leq 0.05$ (Chi $^{2}$ test).

Table 5. Comparison of clinical parameters with the presence of EBV in patients with chronic periodontitis and control group.

\begin{tabular}{|c|c|c|c|c|c|c|c|}
\hline \multirow{2}{*}{ Parameters } & \multirow{2}{*}{ VEB } & \multicolumn{3}{|c|}{$\mathrm{CP}$} & \multicolumn{3}{|c|}{ CG } \\
\hline & & $-\mathrm{N}$ & Average & $p$ value $^{\mathrm{a}}$ & $-\mathrm{N}$ & Average & $p$ value $^{\mathrm{a}}$ \\
\hline \multirow{2}{*}{ PD } & + & 2 & $5.50 \pm 2.12$ & \multirow{2}{*}{0.520} & 1 & $1.00 \pm 0$ & \multirow{2}{*}{0.382} \\
\hline & - & 9 & $4.55 \pm 1.13$ & & 10 & $1.80 \pm 0.63$ & \\
\hline \multirow{2}{*}{ CAL } & + & 2 & $4.00 \pm 0$ & \multirow{2}{*}{0.569} & 1 & $1.00 \pm 0$ & \multirow{2}{*}{0.428} \\
\hline & - & 9 & $4.77 \pm 1.48$ & & 10 & $1.40 \pm 0.51$ & \\
\hline \multirow{2}{*}{ BOP } & + & 2 & $1.00 \pm 0$ & \multirow{2}{*}{-} & 1 & 0 & \multirow{2}{*}{0.740} \\
\hline & - & 9 & $1.00 \pm 0$ & & 10 & $0.10 \pm 0.31$ & \\
\hline \multirow{2}{*}{ PI } & + & 2 & $2.00 \pm 0$ & \multirow{2}{*}{0.118} & 1 & 0 & \multirow{2}{*}{0.428} \\
\hline & - & 9 & $2.33 \pm 0.86$ & & 10 & $0.40 \pm 0.51$ & \\
\hline
\end{tabular}

${ }^{\mathrm{a}} p \leq 0.05$ (Chi ${ }^{2}$ test). 
Herpesviruses may exist in combination in periodontal pockets and act in synergy against host tissues. In this work, the coexistence between HCMV and HSV-1 was found in 18.18\% in AgP cases, and between HSV-1 and EBV in 9.09\% in CP cases. Grouping the three viruses was not found in any samples from AgP and CP patients. Other authors reported an elevated coinfection in the periodontal tissues, like Bilichodmath et al. [1], who shows 78.9\% of mixed infection between HSV-1 and EBV, and 31.5\% between HSV-1 and HCMV in CP group. In the AgP group detected $28.5 \%$ of viral combination between HSV-1 and EBV, and 7.1\% between HSV-1 and HCMV. The viral coexistence has been related to the deepest periodontal samples [28].

Regarding clinical parameters it was evident that the values of AgP group were much higher than those of CP and control groups, showing a significantly statistical difference. Mayorga-Fayad et al. [33] shows that the biggest advance of the clinical indices between groups with periodontitis and control groups was evident, showing greater CAL, BOP and PD in patients with aggressive periodontitis. Botero et al. [19] found that patients with AgP had higher CAL and PD that chronic periodontitis and control group. Imbronito et al. [34] found that the CAL and PI in aggressive and chronic periodontitis groups were significantly higher than in the control group. When making comparisons between groups of periodontitis, they found that the PI and CAL were significantly higher in the aggressive periodontitis group, compared to the chronic periodontitis group.

The BOP mean values in the HCMV positive patients from the AgP group was the only one parameter showing a p value in the borderline, probably due to the sample size and the low viral detection rate. However, the CAL values were more elevated in the HCMV positive patients than in the negative patients. Similar results indicate that HCMV affected sites had greater periodontal destruction, evidenced by high levels of BOP, CAL and PD [19].

The HSV-1 positive patients from the AgP group only show a borderline $p$ value with the BOP parameter, probably due to the sample size. However, Das et al. [32] reported that the values for PD and CAL were increased in those sites positive for the presence of HSV-1 in patients with aggressive periodontitis, compared with those negatives sites. The clinical parameters according to the EBV presence no show any significance difference.

In the last 15 years, it has been proposed that HCMV can be a participant in the pathogenesis of periodontal disease and has been found as one of the most frequently detected virus in periodontitis patients, compared to healthy subjects, because this virus has developed several strategies to evade the host immune response and to take advantage of this response and achieve its reactivation [19]. HCMV uses NFkB to mediate an inflammatory immune response and to induce immediately early gene expression in order to drive viral replication. HCMV encodes the chemokines that draw susceptible monocytes and neutrophils to the site of infection. Consequently, the virus can induce production of IL-1 and TNF- $\alpha$ by macrophages and monocytes, which in turn may up-regulate metalloproteinases (MMPs) and down regulate tissue inhibitors of matrix metalloproteinases (TIMPs) [35].

The HCMV presence in the AgP patients could explain why the dental plaque amount and level of dental care are not often commensurate with disease severity, why the disease tends to occur in a pattern of progression and remission, and why tissue breakdown often appears in a localized and bilaterally symmetrical pattern [36].

In the proposed Slots and Contreras [37] model, infection with Herpesviruses in periodontal tissues may be important in the pathogenesis of periodontitis, due to the alteration of the local response of the host, combined with the presence of other periodontal pathogens. Contreras et al. [15] demonstrated the association between EBV and HCMV-1, with various periodontal pathogenic bacteria. Sharma et al. [38] assessed the HCMV and EBV interaction with Porphyromonas gingivalis and Aggregatibacter actinomycetemcomitans in pathogenesis of aggressive periodontitis. HCMV and EBV were found to have a prevalence of $46.67 \%$ and $40 \%$ respectively, and the viral and bacterial co-infection was found to be $77.78 \%$ between A. actinomycetemcomitans and HCMV. Bacterial lipopolysaccharide (LPS) and HCMV may synergistically activate IL- $1 \beta$ gene transcription, resulting in a markedly increased IL-1 $\beta$ level at periodontal sites, which consequently experience tissue destruction [39].

Herpesviruses can enhance the periodontal disease in two ways, first by direct viral infection and replication, which is organized into time phases, identified with the letters $\alpha, \beta$ and $\gamma$, corresponding to the immediately early, early and late phase, respectively. The second pathway involves host defenses, viral damages and immune evasion. Both pathways may result in decreased ability of tissue repair by cytopathic effects, caused directly on inflammatory and structural cells. All this can lead to an excessive bacterial infection. Furthermore, viral proteins expressed in eukaryotic cell membranes can act as bacterial receptors and generate new binding sites, which may favor the progression of periodontal disease [35] [40]. 
The number of subgingival period onto pathogenic bacteria is probably high because of the active viral infection, which decreases the immune defenses of periodontal tissue. The presence of virus in the periodontal tissues could explain various features of periodontal disease, as: 1-The circumstantial progressive nature of periodontal disease due to transient local immunosuppression depending on the active or latent viral infection. 2-The presence of localized patterns of tissue destruction by viral tropism. 3-Individuals who are carriers of periodontal pathogenic bacteria and still are periodontally healthy due to the absence of viral infection [35].

As reviewed in the literature, there are many reports about the viral infection associated with periodontal disease. Although some of these works present variation between them, this could be due to the number of samples and type of study, the sensitivity and specificity of diagnostic techniques and, finally, the geographical distribution of these viruses in the world population, the socioeconomic status of patients and genetic predisposition, according to the origin of the population.

\section{Conclusion}

These results allow us to suggest that Herpesviruses are associated with the onset and progression of periodontal disease. More studies are needed with larger number of samples. With this information we hope to incorporate our clinical knowledge about the consequences of periodontitis, with the knowledge associated to the molecular mechanisms of tissue destruction by the virus. The development of new research is needed, however, to establish the role of the Herpesviridae family in periodontitis.

\section{Acknowledgements}

This work was funded by the Fondo Nacional de Ciencia, Tecnología e Innovación (FONACIT), project No. G-2005000408.

\section{References}

[1] Bilichodmath, S., Mangalekar, S., Sharma, D., Prabhakar, A., Reddy, S., Kalburgi, N., et al. (2009) Herpesviruses in Chronic and Aggressive Periodontitis Patients in an Indian Population. Journal of Oral Science, 51, 79-86. http://dx.doi.org/10.2334/josnusd.51.79

[2] Contreras, A. and Slots, J. (2000) Herperviruses in Human Periodontal Disease. Journal of Periodontology Research, 35, 3-16. http://dx.doi.org/10.1034/j.1600-0765.2000.035001003.x

[3] Bascones-Martínez, A. and Pousa-Castro, X. (2011) Herpesvirus. Avances en Odontoestomatología, 27, 11-24. http://dx.doi.org/10.4321/S0213-12852011000100002

[4] Zakay-Rones, Z., Ehrlich, J., Hochman, N. and Levy, R. (1973) The Sulcular Epithelium as a Reservoir for Herpes Simplex Virus in Man. Journal of Periodontology, 44, 779-781. http://dx.doi.org/10.1902/jop.1973.44.12.779

[5] Gordon, G., Uhlendorf, C., Baer, P. and Baron, S. (1974) Studies of Herpes Simplex Virus and Interferon in Human Gingival Cell Cultures. Journal of Periodontology, 46, 86-89. http://dx.doi.org/10.1902/jop.1975.46.2.86

[6] McLennan, J. and Darby, G. (1980) Herpes Simplex Virus Latency: The Cellular Location of Virus in Dorsal Root Ganglia and the Fate of the Infected Cell Following Virus Activation. Journal of General Virology, 51, 233-243. http://dx.doi.org/10.1099/0022-1317-51-2-233

[7] Zakay-Rones, Z., Hochman, N. and Rones, Y. (1981) Immunological Response to Herpes Simplex Virus in Human Gingival Fluid. Journal of Periodontology, 53, 42-45. http://dx.doi.org/10.1902/jop.1982.53.1.42

[8] Hochman, N., Rones, Y., Ehrlich, J., Levy, R. and Zakay-Rones, Z. (1981) Antibodies to Herpes Simplex Virus in Human Gingival Fluid. Journal of Periodontology, 52, 324-326. http://dx.doi.org/10.1902/jop.1981.52.6.324

[9] Rones, Y., Hochman, N., Ehrlich, J. and Zakay-Rones, Z. (1982) Sensitivity of Oral Tissues to Herpes Simplex Virus-in Vitro. Journal of Periodontology, 54, 91-95. http://dx.doi.org/10.1902/jop.1983.54.2.91

[10] Honess, R. (1984) Herpes Simplex and "the Herpes Complex". Diverse Observations and a Unifying Hypothesis. Journal of General Virology, 65, 2077-2107. http://dx.doi.org/10.1099/0022-1317-65-12-2077

[11] Kameyama, T., Sujaku, C., Yamamoto, S., Hwang, C. and Shillitoe, E. (1988) Shedding of Herpes Simplex Virus Type 1 into Saliva. Journal of Oral Pathology, 17, 478-481. http://dx.doi.org/10.1111/j.1600-0714.1988.tb01320.x

[12] Ehrlich, J., Cohen, G. and Hochman N. (1982) Specific Herpes Simplex Virus Antigen in Human Gingival. Journal of Periodontology, 54, 357-359. http://dx.doi.org/10.1902/jop.1983.54.6.357

[13] Contreras, A. and Slots, J. (1996) Mammalian Viruses in Human Periodontitis. Oral Microbiology and Immunology, 11, 381-386. http://dx.doi.org/10.1111/j.1399-302X.1996.tb00199.x 
[14] Contreras, A., Flakler, W., Enwonwu, C., Idigbe, E., Savage, K., Afolabi, M., et al. (1997) Human Herpesviridae in Acute Necrotizing Ulcerative Gingivitis in Children in Nigeria. Oral Microbiology and Immunology, 12, 259-265. http://dx.doi.org/10.1111/j.1399-302X.1997.tb00389.x

[15] Contreras, A., Umeda, M., Chen, C., Bakker, I., Morrinson, J. and Slots, J. (1999) Relationship between Herpesviruses and Adult Periodontitis and Periodontophatic Bacteria. Journal of Periodontology, 70, 478-484. http://dx.doi.org/10.1902/jop.1999.70.5.478

[16] Contreras, A. and Slots, J. (1999) Herpesviruses in Human Periodontal Diseases. Journal of Periodontal Research, 35 3-16. http://dx.doi.org/10.1034/j.1600-0765.2000.035001003.x

[17] Contreras, A., Zadeh, H., Nowzari, H. and Slots, J. (2000) Herpesviruses Infection of Inflammatory Cells in Human Periodontitis. Oral Microbiology and Immunology, 14, 206-212. http://dx.doi.org/10.1034/j.1399-302X.1999.140402.x

[18] Parra, B. and Slots, J. (1996) Detections of Human Viruses in Periodontal Pockets Using Polymerase Chain Reaction. Oral Microbiology and Immunology, 5, 289-293. http://dx.doi.org/10.1111/j.1399-302X.1996.tb00183.x

[19] Botero, J., Parra, B. and Contreras, A. (2008) Citomegalovirus y microorganismos periodontopáticos subgingivales en periodontitis crónica y agresiva. Revista Odontológica Mexicana, 12, 70-75.

[20] Eres, G., Altık, E., Ozkul, A. and Açıkel, C. (2011) Subgingival Epstein Barr and Cytomegalovirus Occurrence in Pregnancy Gingivitis. Journal of Periodontology, 82, 1676-1684. http://dx.doi.org/10.1902/jop.2011.100587

[21] Armitage, G.C. (1999) Development of a Classification System for Periodontal Diseases and Conditions. Annals of Periodontology, 4, 1-6. http://dx.doi.org/10.1902/annals.1999.4.1.1

[22] Silness, J. and Loe, H. (1964) Periodontal Disease in Pregnancy. Correlation between Oral Hygene and Oral Condition. Acta Odontologica Scandinavica, 22, 121-135. http://dx.doi.org/10.3109/00016356408993968

[23] Van Dongen, J., Langerak, A., Brüggemann, M., Evans, P., Hummel, M., Lavender, F., et al. (2003) Design and Standardization of RCP Primers and Protocols for Detection of Clonal Immunoglobulin and T-Cell Receptor Gene Recombinations in Suspect Lymphoproliferations: Report of the BIOMED-2 Concerted Action BMH4 CT98-3936. Leukemia, 17, 2257-2317. http://dx.doi.org/10.1038/sj.leu.2403202

[24] Hilders, I. (2002) Relación entre el grupo de virus de la familia Herpesviridae y la Enfermedad Periodontal. Specialization Dissertation, Central University of Venezuela, Caracas.

[25] León, M. and Radovan, M. (2004) Relación entre Herpes Virus y la Periodontitis. Fórmula Odontológica, 2, 210-215.

[26] Slots, J. and Slots, H. (2011) Bacterial and Viral Pathogens in Saliva: Disease Relationship and Infectious Risk. Periodontology, 55, 48-69. http://dx.doi.org/10.1111/j.1600-0757.2010.00361.x

[27] Kamma, J., Contreras, A. and Slots, J. (2004) Herpes Viruses and Periodontopathic Bacteria in Early-Onset Forms of Periodontal Disease. Journal of Clinical Periodontology, 39, 81-86.

[28] Ting, M., Contreras, A. and Slots, J. (2000) Herpesviruses in Localized Juvenile Periodontitis. Journal of Periodontal Research, 35, 17-25. http://dx.doi.org/10.1034/j.1600-0765.2000.035001017.x

[29] Yapar, M., Saygun, I., Ozdemir, A., Kubar, A. and Sahin, S. (2003) Prevalence of Human Herpesviruses in Patients with Aggressive Periodontitis. Journal of Periodontology, 74, 1634-1640. http://dx.doi.org/10.1902/jop.2003.74.11.1634

[30] Sharma, R., Padmalatha, O., Kaarthikeyan, G., Jayakumar, N., Varghese, S. and Sherif, K. (2012) Comparative Analysis of Presence of Cytomegalovirus (CMV) and Epstein Barr Virus-1 (EBV-1) in Cases of Chronic Periodontitis and Aggressive Periodontitis with Controls. Indian Journal of Dental Research, 23, 454-458. http://dx.doi.org/10.4103/0970-9290.104948

[31] Watanabe, S., Correia, J., Rebello, M., Da costa, J. and Gomez, R. (2007) EBV 1 and HCMV in Aggressive Periodontitis in Brazilian Patients. Brazilian Oral Research, 21, 336-341. http://dx.doi.org/10.1590/S1806-83242007000400010

[32] Das, S., Prakash, S. and Gopalakrishnan, S. (2012) Detection of Human Herpes Viruses in Patients with Chronic Periodontitis and Relationship between Viruses and Clinical Parameters. Journal of Oral and Maxillofacial Patholgy, 16, 203-209. http://dx.doi.org/10.4103/0973-029X.98502

[33] Mayorga-Fayad, I., Lafaurie, G., Contreras, A., Castillo, D., Barón, A. and Aya, M. (2007) Microflora subgingival en periodontitis crónica y agresiva en Bogotá, Colombia: un acercamiento epidemiológico. Biomédica, 27, 21-33. http://dx.doi.org/10.7705/biomedica.v27i1.230

[34] Imbronito, A., Okuda, O., De Freitas, N., Fraga, R. and Daumas, F. (2008) Detection of Herpesviruses and Periodontal Pathogens in Subgingival Plaque of Patients with Chronic Periodontitis, Generalized Aggressive Periodontitis, or gingivitis. Journal of Periodontology, 79, 2313-2321. Http://Dx.Doi.Org/10.1902/Jop.2008.070388

[35] Beader, N. and Ivić-Kardum, M. (2011) The Role of Cytomegalovirus Infection in the Pathogenesis of Periodontal Diseases. Acta Clinica Croatica, 50, 61-66. 
[36] Saygun, I., Kubar, A., Özdemir, A., Yapar, M. and Slots, J. (2004) Herpesviral-Bacterial Interrelationships in Aggressive Periodontitis. Journal of Periodontal Research, 39, 207-212. http://dx.doi.org/10.1111/j.1600-0765.2004.00728.x

[37] Slots, J. and Contreras, A. (2000) Herpesviruses: A Unifying Causative Factor in Periodontitis? Oral Microbiology and Immunology, 15, 277-280. http://dx.doi.org/10.1034/j.1399-302x.2000.150501.x

[38] Sharma, S., Tapashetti, R., Patil, R., Kalra, S., Bhat, G. and Guvva, S. (2015) Revelation of Viral-Bacterial Interrelationship in Aggressive Periodontitis via Polymerase Chain Reaction: A Microbiological Study. Journal of International Oral Health, 7, 101-107.

[39] Wara-aswapati, N., Boch, J.A. and Auron, P.E. (2003) Activation of Interleukin 1 Gene Transcription by Human Cytomegalovirus: Molecular Mechanisms and Relevance to Periodontitis. Oral Microbiology and Immunology, 18, 67-71. http://dx.doi.org/10.1034/j.1399-302X.2003.00053.x

[40] Dimmock, N., Easton, A. and Leppard, K. (2007) Introduction to Modern Virology. 6th Edition, Blackwell Publishing, Oxford, 139-140. 